\title{
Aeromonas-related Diarrhoea in Nasarawa, Nigeria
}

\author{
${ }^{1}$ Y. T. Kandakai-Olukemi, ${ }^{2}$ J. D. Mawak, ${ }^{3}$ M. A. Olukemi and ${ }^{1}$ S. O. Ojumah \\ Department of Medical Microbiology, Faculty of Medical Sciences, Department of Microbiology, Faculty of \\ Natural Sciences, and Department of Pharmaceutics and Pharmaceutical Technology, \\ University of Jos, Jos, Nigeria \\ Reprint requests to: Dr. Y. T. Kandakai-Olukemi, P. M. B. 2084, Department of Medical Microbiology, Faculty \\ of Medical Sciences, University of Jos, P. M. B. 2084, Jos, Nigeria.E-mail: mawakj@unijos.edu.ng
}

\begin{abstract}
Background: Two hundred and fifty volunteer patients attending 5 major hospitals in Nasarawa town, Nasarawa State, Nigeria were involved in this study to determine the prevalence of Aeromonas spp in persons with diarrhoea. The study population consisted of 133 males and 117 females between the ages of 0-70 years.

Methods: Stool samples (148 diarrhoeal and 102 non-diarrhoeal) were analysed for the presence of Aeromonas spp. using standard bacteriological methods. The isolates were also subjected to antimicrobial susceptibility testing using the disc diffusion method.

Results: Four (1.60\%) of the 250 stool samples were positive for Aeromonas spp. Three $(2.03 \%)$ of the isolates were recovered from diarrhoeal specimens and $1(0.98 \%)$ from non-diarrhoeal (control) samples. The difference was statistically significant $(\mathrm{P}<0.05)$. The highest numbers of isolates $3(3.66 \%)$ were recovered from age group 0-10 years while age group 61-70 years yielded 1 (14.29\%). All isolates were found to be Aeromonas hydrophilia. The isolates were all sensitive to tetracycline, gentamicin, chloramphenicol, cotrimoxazole and streptomycin but resistant to penicillin and ampicillin. Other enteropathogens isolated were Shigella spp 5 (2.0\%) and Salmonella spp 2(0.8\%).

Conclusion: This study has shown that a small percentage of gastroenteritis can be attributed to Aeromonas hydrophilia.
\end{abstract}

Key words: Aeromonas, diarrhoea

\begin{abstract}
Résumé
Introduction: Deux cents cinquante patients volontaaires qui consultent 5 hôpitaux majeurs dans la ville de Nasarawa l'Etat de Nasarawa, Nigéria ont participé dans cette étude pour décider la fréquence d'aeromone spp chez des individus atteints de la diarrhée. La population d'étude se compose de 133 du sexe masculin et 117 du sexe féminin entre $0-70$ ans.

Méthodes: Echantillons des fèces (148 diarrhée et 102 non - diarrhée) ont été analysés pour la présence d'aeromone spp à travers l'utilisation de la méthode bactériologique. Les isolates étaient également en butte d'examen de la susceptibilité antimicrobiale à travers l'utilization de la méthode de diffusion de disque.

Résultats: Quatre soit 1,60\% de 250 échantillons de fèces étaient positifs pour l'aeromone spp. Trois soit $2,03 \%$ des isolates ont été soignés des spécimens de la diarrhée et 1 soit $0,98 \%$ des échantillons nondiarrhée (contrôle). La différence était statistiquement importante $(\mathrm{p}<0,05)$. Nombre le plus élevé des isolates 3(3,66\%) ont été soignés d'une trance d'âge $0-10$ ans, tandis que groupe d'âge 61070 ans donnent 1 soit 14,29\%. On avait trouvé que toutes les isolates étaient arromone hydrophilie. Toutes les isolates étaient sensibles à la tétracycline, gentamicine, chloramphénicol cotrimoxazole et stréptomycine mais résistant à la pénicilline et ampicilline, Des autres isolates enteropathogens étaient shigella spp 5 soit 2,0\% et salmonella spp. 2(0,8\%)
\end{abstract}

Conclusion: A travers cette étude on peut conclure que un petit pourcentage de la gastroenterite peut être attribuable au aeromone hydrophlilie.

Mots-clés: Aeromone, diarrhée 


\section{Introduction}

Aeromonas species are gram-negative bacteria of the family, Aeromonadaceae. ${ }^{1}$ They have been implicated in a range of infections from skin and soft tissues, bacteraemia to gastroenteritis. ${ }^{2}$ Acute watery diarrhoea with a short duration is the most common clinical feature. ${ }^{3}$ Host factors seem to be strongly related to the diarrhoea associated with Aeromonas. It appears that all age groups are susceptible to gastroenteritis caused by Aeromonas, however it is most frequently observed in young children (under 5 years of age) older adults (over 60 years of age) and the immunocompromised. ${ }^{4-6}$ Individuals suffering from leukemia, carcinoma, diabetes mellitus, hepatitis and cirrhosis or those being treated with immunosuppressive drugs or who are undergoing cancer chemotherapy may be susceptible to systemic infections caused by Aeromonas. ${ }^{7}$

The occurrence of a haemolytic-uremic syndrome following an Aeromonas gastroenteric disease has been reported. ${ }^{\mathbf{8}}$ The syndrome is similar to that associated with Escherichia coli 0157:H7 and is caused by an Aeromonas cytotoxin. Aeromonas infection is strongly associated with untreated water and common species associated with human illness are A. hydrophilia, A. caviae and A. sobria. It has been suggested that isolating these organisms from well defined population might help in the understanding of the prevalence of Aeromonas and their potential to cause gastroenteritis. Therefore this study was carried out to determine the prevalence of Aeromonas spp in children and adults with diarrhoea.

\section{Materials and Methods}

\section{Study population}

The study population was drawn from volunteer patients attending 5 major hospitals in Nasarawa town, Nigeria (comprehensive health centre, Alpha hospital, Henard Medical centre, Zumunchi Clinic and Maternity and Federal Polytechnic Medical Centre). A total of 250 (148 diarrhoeal and 102 non diarrhoeal) stool samples were collected.

Informed consent was obtained from the patients, hospital authorities and clinicians involved in the management of the patients.

\section{Sample collection}

Stool samples were collected from patients in clear, transparent wide mouthed bottles. Information was also obtained from each patient regarding age, sex, major symptoms (diarrheoa, vomiting and fever) and duration of disease.

\section{Processing of specimens}

The specimens were processed according to guidelines provided by Cheesbrough ${ }^{9}$ for the laboratory diagnosis of enteric pathogens. These include macroscopy, microscopy, Gram's stain, motility testing, culture, biochemical testing and antimicrobial sensitivity testing. Specimens were inoculated into 5\% sheep blood agar containing $30 \mu \mathrm{g} / \mathrm{ml}$ ampicillin. The inoculated plates were incubated aerobically at $37^{\circ} \mathrm{C}$ for 24 hours. Resultant colonies were identified using standard biochemical tests.

\section{Biochemical testing}

Colonies showing beta haemolysis on sheep blood agar were further subjected to the following standard tests: Gram's staining, oxidase test, indole test, urease test, citrate utilization test, and test to determine motility after distilled water and peptone water subcultures. All tests were done using the methods described by Collee and Miles ${ }^{\mathbf{1 0}}$ and Porter and Duguid. ${ }^{11}$

\section{Characterization of species}

Isolates were characterized to the species level based on seven biochemical tests as described by Carnahan et al. ${ }^{12}$ These included aesculin hydrolysis, gas from glucose, acid from arabinose, indole production, acid from sucrose, Voges-Proskauer reaction and resistance to cephalothin $(30 \mu \mathrm{g})$.

\section{Antimicrobial susceptibility testing}

Sensitivity of isolates to antimicrobial agents was determined on Mueller-Hinton agar plates using the disc diffusion method of Scott. ${ }^{13}$ Interpretation of results was done using the zone sizes. All isolates were tested for sensitivity to the following antibiotics: ampicillin $(10 \mathrm{mcg})$, tetracycline $(10 \mathrm{mcg})$, gentamicin (10mcg), chloramphenicol (10mcg), cotrimoxazole $(25 \mathrm{mcg})$, streptomycin $(10 \mathrm{mcg})$ and penicillin $\mathrm{G}$ (5mcg) all of Antec Diagnostics, UK.

Data was analysed using SPSS statistical software.

\section{Results}

A total of 250 (148 diarrhoeal and 102 nondiarrhoeal) stool samples were examined. The age range of the patients was from 0-70 years.

Of the total number of specimens examined, $4(1.60 \%)$ were positive for Aeromonas spp. 3(2.03\%) of which were recovered from diarrhoeal stool specimens while $1(0.98 \%)$ was from the nondiarrhoeal (control) samples. The difference is statistically significant $(\mathrm{p}<0.05)$. Also, Aeromonas $\mathrm{spp}$ was isolated from $2(1.50 \%)$ of the 133 stool samples collected from males and $2(1.71 \%)$ of the 117 samples collected from females (Table 1).All the isolates were found to be Aeromonas hydrophila. The highest numbers of isolates $3(3.66 \%)$ were recovered from the age group 0-10 years. The age group 61-70 years yielded $1(14.29 \%)$ isolate. No isolates were recovered from all the other age groups (Table 2$)$. The difference is statistically significant $(\mathrm{p}<0.05)$.

Macroscopic examination of the stool samples showed that 120 were watery, 12 mucoid and blood stained, 16 soft formed and 102 hard formed. The watery specimens, yielded the highest number of isolates $2(1.67 \%)$, soft-formed $1(6.25 \%)$ and hard formed $1(0.98 \%)$. The mucoid and blood stained 
specimens yielded no isolates (Table 3).

Table 4 shows the in-vitro antibiotic susceptibility pattern of the isolates. All $(100 \%)$ of the isolates were sensitive to tetracycline, gentamicin, chloramphenicol, cotrimoxazole and streptomycin. Also, all the isolates were resistant to penicillin $\mathrm{G}$ and ampicillin. Other enteropathogens isolated were Shigella spp 5 (2.0\%) and Salmonella spp 2(0.8\%).

Table 1: Age-related prevalence of Aeromonas species among patients with or without diarrhoea

\begin{tabular}{lllllll}
\hline Patients & $\begin{array}{l}\text { No. } \\
\text { specimens }\end{array}$ & Male & & Female & & $\begin{array}{l}\text { Total No. } \\
\text { positive (\%) }\end{array}$ \\
\hline & & $\begin{array}{l}\text { No. } \\
\text { examined }\end{array}$ & $\begin{array}{l}\text { No. Positive } \\
(\%)\end{array}$ & $\begin{array}{l}\text { No. } \\
\text { examined }\end{array}$ & $\begin{array}{l}\text { No. positive } \\
(\%)\end{array}$ & \\
With diarrhoea & 148 & 78 & $2(2.56)$ & 70 & $1(1.42)$ & $3(2.03)$ \\
Without diarrhoea & 102 & 55 & - & 47 & $1(2.12)$ & $1(0.98)$ \\
\hline Total & 250 & 133 & $2(1.50)$ & 117 & $2(1.71)$ & $4(1.60)$ \\
\hline
\end{tabular}

Table 2: Prevalence of Aeromonas species isolated and age

\begin{tabular}{lll}
\hline $\begin{array}{l}\text { Age } \\
\text { (years) }\end{array}$ & $\begin{array}{l}\text { No. of specimens } \\
\text { examined }\end{array}$ & No. positive (\%) \\
\hline $0-10$ & 82 & $3(3.66)$ \\
$11-20$ & 45 & - \\
$21-30$ & 64 & - \\
$31-40$ & 31 & - \\
$41-50$ & 12 & - \\
$51-60$ & 9 & - \\
$61-70$ & 7 & $1(14.29)$ \\
\hline Total & 250 & $4(1.60)$ \\
\hline
\end{tabular}

Table 3: Types of samples treated and Aeromonas species isolated

\begin{tabular}{lll}
\hline $\begin{array}{l}\text { Type of stool } \\
\text { sample }\end{array}$ & No. examined & No. positive (\%) \\
\hline Watery & 120 & $2(1.67)$ \\
$\begin{array}{l}\text { Mucoid and } \\
\text { blood stained }\end{array}$ & 12 & - \\
Soft formed & 16 & $1(6.25)$ \\
Hard formed & 102 & $1(0.98)$ \\
\hline Total & 250 & $4(1.60)$ \\
\hline
\end{tabular}

Table 4: In-vitro antibiotic susceptibility pattern of Aeromonas species isolated

\begin{tabular}{lll}
\hline $\begin{array}{l}\text { Antibiotic } \\
\text { (concentration in Mcg) }\end{array}$ & No. tested & $\begin{array}{l}\text { No. } \\
\text { sensitive }\end{array}$ \\
\hline Ampicillin (10 & 4 & - \\
Tetracycline (10) & 4 & 4 \\
Gentamicin (10) & 4 & 4 \\
Chloramphenicol (10) & 4 & 4 \\
Cotrimoxazole (25) & 4 & 4 \\
Streptomycin (10) & 4 & 4 \\
Penicillin G (5) & 4 & - \\
\hline
\end{tabular}

\section{Discussion}

A total of 250 stool samples were analysed in this study in which the prevalence rate for Aeromonas spp was $1.6 \%$. This result is lower than the $5 \%$ prevalence rate documented by Obi et al ${ }^{\mathbf{1 4}}$ for urban population in Edo, Lagos and Cross River States of Nigeria. It is also lower than the $5.8 \%$ reported by KandakaiOlukemi et al ${ }^{\mathbf{1 5}}$ for children in Jos, Nigeria. There was a higher isolation rate for persons with diarrhoea compared to those without diarrhoea which is a reverse of the findings from the Jos study. The difference is statistically significant. It should be noted that the study conducted by Kandakai-Olukemi et al ${ }^{\mathbf{1 5}}$ involved children 6 years and younger, the age range in which Aeromonas diarrhoea is frequently observed. ${ }^{6}$ This study however, involved persons from 0 to 70 years. This might probably account for differences in isolation rates. The fact that Aeromonas spp. was isolated only from the extremes of ages supports this assertion.

Findings from this study indicate that isolation rates for Aeromonas were higher in age range $0-10$ years and $61-70$ years, which corroborates findings by other workers. ${ }^{4-6}$ No difference was observed in isolation of Aeromonas for males and females and sex preference has not been reported.

Macroscopic examination of stool samples showed that the highest number of Aeromonas spp was isolated from watery stools. This is in agreement with reported findings that acute watery diarrhoea is the most common clinical feature associated with Aeromonas. $^{3}$

In vitro antibiotic sensitivity test showed that the Aeromonas isolates were sensitive to all common antibiotics tested with the exception of penicillin $G$ and ampicillin. The marked susceptibility of the Aeromonas isolates to antibiotics such as tetracycline, chloramphenicol, cotrimoxazole and streptomycin is contrary to reported findings for some Aeromonas strains ${ }^{15}$ and many enteric bacteria isolated in other parts of Nigeria. ${ }^{17}$ Aeromonas resistance to the penicillins is well documented and appears to be genetically induced. ${ }^{2}$

All isolates identified were found to be Aeromonas hydrophilia and this Aeromonas spp has been associated with many cases of diarrhoea. ${ }^{1}$

In this study two bacterial genera were also isolated, namely Salmonella and Shigella species. 
These bacteria are common aetiologic agents of gastroenteritis in our environment hence, their presence in diarrhoeal, stool implicate them in the infection. However, the four isolates of Aeromonas hydrophilia were not found to co-infect with the other organisms. This finding indicates that they were probably the primary infecting agents in cases where they were isolated.

In conclusion, this study has shown that even though the isolation rate is low when compared with other enteric pathogens, a small percentage of gastroenteritis can be attributed to Aeromonas hydrophilia

\section{References}

1. Kayser FH, Bienz KA, Eckert J, Zinkernagel RM. Medical microbiology. Thieme Verlag, Stuttgart, 2005; 224

2. Jones BL, Wilcox MH. Aeromonas infections treatment. J Antimicrob Chemother 1995; 35: 453-461

3. Albert MJ, Ansaruzzaman M, Talukder KA. Prevalence of enterotoxin in genes of Aeromonas spp isolated from children with diarrhoea, healthy controls and environment. J Clin Microbiol 2000; 38: $3785-3790$

4. Gracey M, Burke V, Robinson J. Aeromonas associated gastroenteritis. Lancet 1982; 2: 13041306

5. Burke V, Gracey M. The microbiology of childhood gastroenteritis: Aeromonas spp and other infective agents. J Infect Dis 1983; 148: $68-74$

6. Rathinasamy S, Thangavelu T, Govindhasamy V. Occurrence of Aeromonas in acute gastroenteritis among children. Indian J Med Res 2006; 123: 4651

7. http://www.hpa.org.uk/infections/topicsaz/aeromonas/menu.htm.

8. Janda JM, Abbott SL. Evolving concepts regarding the genus Aeromonas: an expanding panorama of species, disease presentation, and unanswered question. Clin Infect Dis 1998; 27: $332-338$
9. Cheesbrough M. Medical laboratory manual for tropical countries. Cambridge University, Cambridge, 1985; 2: 192-193

10. Collee JG, Miles RS. Tests for identification of bacteria. In: Collee JG, Duguid JP, Fraser AG, Marmion BP (eds). Mackie and McCartney's practical medical microbiology. ELBS, London, 1989; 141-160

11. Porter IA, Duguid JP. Vibrio, Aeromonas Plesiomonas, Spirillum, Campylobacter. In: Collee JG, Duguid JP, Fraser AG, Marmion BP (eds). Mackie and Mc Cartney's practical medical microbiology. ELBS, London, 1989; 505-524

12. Carnahan AM, Behram S, Joseph SW. Aerokey II: a flexible key for identifying clinical Aeromonas species J Clin Microbiol 1991; 29:2843-2849

13. Scott AC. Laboratory control of antimicrobial therapy. In: Collee JG, Duguid JP, Fraser AG, Marmion BP (eds). Mackie and McCartney's practical medical microbiology. ELBS, London, 1989; 161-181

14. Obi CL, Coker Epoke J, Dnip RN. Enteric bacterial pathogens in stool of residents of urban and rural regions in Nigeria: a comparison of patients with and without diarrhoea and controls without diarrhoea. J Diarrhoeal Dis Res 1997; 15: 241-247

15. Kandakai-Olukemi YT, Mawak JD, Ochai IJ, Olukemi MA. Isolation of Aeromonas species from children with and without diarrhoea in Jos, Nigeria. African Journal of Clinical and Experimental Microbiology (in press)

16. Opajobi SO, Kandakai-Olukemi YT, Mawak JD, Olukemi MA, Bello CSS. Vibrio cholerae infections in Jos. African Journal of Clinical and Experimental Microbiology 2004; 5: 267-271

17. Kandakai-Olukemi YT, Okewu MS, Mawak JD, Olukemi MA, Zumbes HJ. Prevalence of Yersina enterocolitica among patients in Jos and environs. Journal of Pharmacy Bioresoruces 2004; 1: 46-50

18. Agger WA, McCormick JD, Gurwith MJ. Clinical and microbiological features of Aeromonas associated diarrhoea. J Clin Microbiol 1985; 21: 909-913 